\title{
The Case of Hellmuth in The Autistic Psychopathy - Suffering from Cushing Syndrome?
}

\section{Dr.Med Benedikt Gasser* \\ Faculty of Medicine, University of Bern, Switzerland, Europe}

Submission: June 12, 2018; Published: June 21, 2018

*Corresponding author: Med Benedikt Gasser, Faculty of medicine, University of Bern, Zellmoosweg 336210 Sursee, Switzerland,

Email: gasser@pyl.unibe.ch

\begin{abstract}
Autism spectrum disorders are increasingly linked to an altered endocrine metabolism and it was hypothesized that any disturbances in Hypothalamus-Pituitary adrenal gland axis respectively steroid hormone metabolism is reflected in the habitus of affected autistic individuals. One case described by Hans Asperger [1] was Hellmuth - at the time of description an 11-year-old boy - for whom strong indicators concerning an endocrine pathology can be found. If comparing with Cushing syndrome remarkable similarities can be identified. Weak bones would be in line with a glucocorticoid induced osteoporosis or even rachitis with involvement of thyroid and parathyroid glands. Interestingly, Hellmuth was treated with thyroid and hypothalamus hormones not having substantial effects. He was described having a face with hanging chops and with a small head remembering of a microcephalus, which can be further interpreted as signs of a typical Cushing Habitus. Laboratory parameters are missing, but the clinical signs are relatively straight forward, and an endocrinology involvement was explicitly mentioned by Hans Asperger [1]. Probably, hormones from different classes' glucocorticoids, mineralocorticoids and androgens were involved. Furthermore, mentioned sleep disturbances are in line with a dysregulation of Melatonin Stimulating Hormone on pineal gland level and the abnormal diet might be a result of a dysregulation of Insulin and Glucagon homeostasis in line with a general endocrine dysregulation in this autistic individual suffering from Asperger Syndrome.
\end{abstract}

Keywords: Asperger Syndrome; Endocrine involvement; Hypothalamus-Pituitary adrenal gland; Steroid hormones

\section{Introduction}

Autism spectrum disorders are uniformly defined as an individual's impaired social interaction, communication deficits, as well as repetitive and restricted interests and behaviour. This definition is symptomatic and behavioural, yet not causative[2]. Autism is inexplicably biased towards males by a ratio of around $4: 1$, with no clear understanding of the role of sex hormones

in autism[1,3]. Addressing the hypothalamic pituitary adrenal (HPA) axis has a long history in studying neurocognitive aspects of diseases such as autism. [4-8] Increasing evidence exists for a dysregulation of the hypothalamic-pituitary adrenal axis (HPA-axis) in autism and thus of steroid hormones of adrenal gland mineralocorticoid, glucocorticoid and androgen metabolites[4,5,8-11].

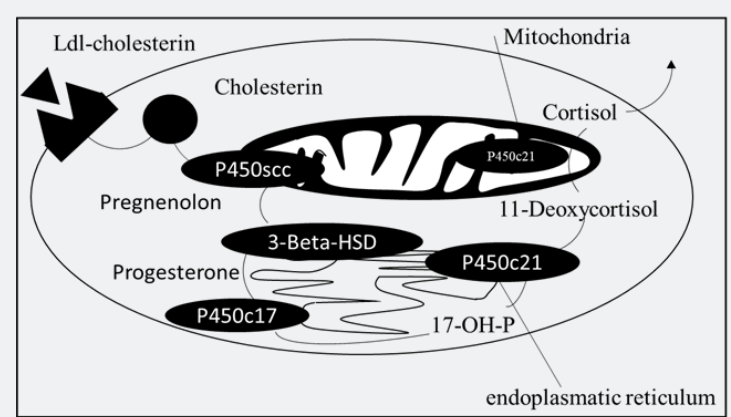

Figure 1: From Acetate to cholesterol as precursor of steroid metabolites. Interestingly, progesterone is not only metabolized in the adrenal gland and sex organs but also in the kidney and liver. Focusing on progesterone synthesis, conversion from cholesterol to pregnenolone takes place in mitochondria through a P450-enzyme complex (hydroxylase/desmolase) which is induced through ACTH, linking the metabolite synthesis pathway with the HPA-axis implying that progesterone acts as a pro-hormone for androgens and estrogens[14]; [15]; [16]. 
These metabolites are characterized through cholesterol as precursor allowing to suggest that all steroids are involved in autism. A link between cholesterol, vitamin D, and steroid hormones which subsequently impacts on the development of at least some cases of autism have already been suggested. $[12,13]$ (Figure 1). To pinpoint, Hypothalamic-pituitary adrenal gland (HPAG)-axis and androgens were several times addressed as involved in autistic disorders[4,5,8-11]. In the following part an impressive case of an 11-year-old boy described by Hans Asperger [1] shall be analysed concerning an endocrine involvement.

\section{Evidence Acquisition}

Having a look on the description of Hans Asperger in his original work autistic psychopathy in 1944 one impressive case of a boy exists, which shall be analyzed concerning an endocrineinvolvement[1]. Hellmuth was at the first time of examination at the clinic an 11-year-old boy. He was always fat, despite strictly observed diet by medical doctors[1]. Fatty breasts, both sided maldescensus testis in combination with inadequate sexual behavior [1]. Treatment was started with thyroid and pituitary gland medication without effects on maldescencus testis and obese habitus[1]. Joints could be easily overstretched, shaking hands let feel like he has no bones, imposing Genua valga and flat foot were described. Habitus was described as antic, on the massy body over the face with hanging chops a little head (described as microcephalus) with close standing eyes[1]. Unable to catch a ball even when making it very easy for him with abnormal movements[1]. Furthermore, the special interests were described for poems and lyrics as usual in this Syndrome[17-20]. Furthermore, clear hints exist, that the whole personality was involved [1]. A perinatal trauma with a cerebral disorder was further mentioned, whereby detailed anamnesis reveals asphyxia during birth with reanimation followed by repeated convulsions, an endocrine disorder was explicitly mentioned, the altered flow of saliva probably thereforea dysfunction of the vegetative nerve system supports the hypothesis of an endocrine involvement.

Interestingly, no illnesses were described for parents, however mother was relatively old with 41 years. Hellmuth was always fat, despite consequent and observed diet. To sum up, analyzing the case of Hellmuth some astonishing hints concerning an endocrine pathology with involvement of steroid hormones and Hypothalamus-Pituitary-Adrenal Axis can be found. Very common in autism are sleep disturbances - also described by Hans Asperger [1] in affected individuals - in line with a dysregulation of Melatonin and Cortisol homeostasis and dietary anomalies in line with Insulin, Glucagon and Cortisol homeostasis. Figure 2 summarizes some clinical symptoms of a Cushing syndrome ingoing with an endocrine dysregulation as described by Hans Asperger [1] for Hellmuth.

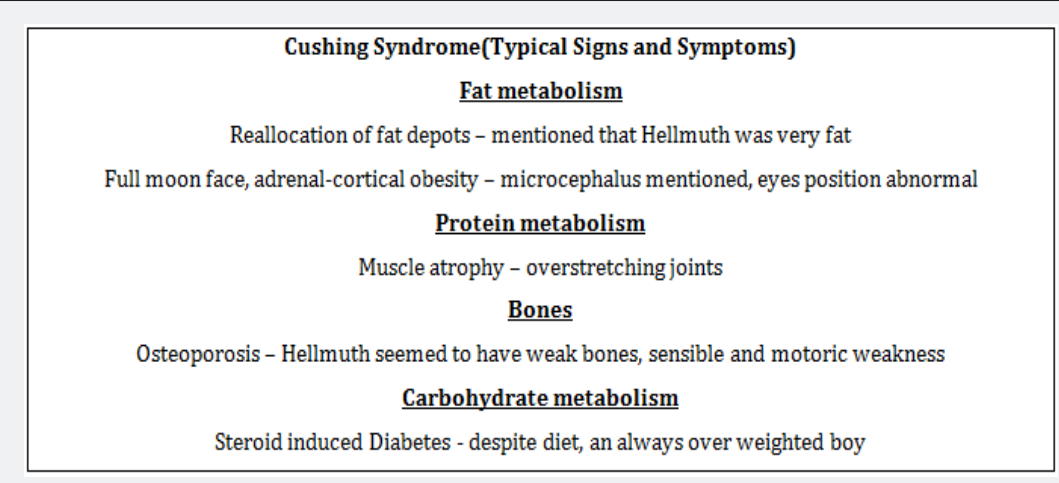

Figure 2: The description of Hellmuth versus the typical symptomatic ongoing with Cushing syndrome - some similarities can be found.

\section{Discussion}

The aim of these analyses was to find hints in the described case by Hans Asperger [1] for Hellmuth concerning an endocrine involvement and to imbed it in the actual literature concerning an endocrine involvement in autism. Clear hints concerning a dysregulation of androgens, glucocorticoids and mineralocorticoids or broader on general endocrine level with involvement of different anatomic structures from Hypothalamus-pituitary adrenal gland or thyroid respectively parathyroid system can be found. This implies a general dysregulation. Due to hints concerning a Cushing habitus probably steroid hormones were involved such as Cortisol or typical sex hormones such as Testosterone, Progesterone's or Estrogens. Focusing on clinical symptoms and the androgen theory of autism fetal testosterone levels are reported to be positively correlated with a number of autistic traits and inversely correlated with social development and empathy, allowing to link steroid metabolites with autistic behavior [9].

It has been shown that significantly more women with autism reported hirsutism, bisexuality or asexuality, irregular menstrual cycle, dysmenorrhea, polycystic ovary syndrome, severe acne, and a family history of ovarian, uterine and prostate cancer[21]. Furthermore, it was shown,that androgens and estrogens differentially and reciprocally regulate retinoic orphan receptor A (RORA), a novel candidate gene for autism implying a hereditable disorder and in line withthe original description[1,3]. Interestingly, RORA regulates neuronal Aromatase, which converts androgen to estrogen implying a 
dysregulation of the differentsteroid metabolites in autism $[3,22]$. Alterations of steroid hormones may lead to a potential autistic phenotype in line with extreme male theory of autism, whereby in principle all sorts of steroid hormones were suggested to be involved[9,21,23]. Furthermore, progesterone metabolites were recently identified as part of the neuroendocrine basis of social bonds and enable individuals to suppress self-interest when necessary to promote the well-being of another person highly congruent with behavioural traits in autistic disorders[24,25]. This would be in accordance with a hypercortisolism and an involvement of CRH-ACTH system for which clear hints for Hellmuth can be found $[4,8,26]$. Finally, a special role on androgen metabolism is likely due to an observed diabetic effect of the substance[27,28].

A dysregulation of insulin, glucagon and IGF factors was described in autistic individuals, for Hellmuth clear hints according this symptomatic can be found. In the analysed case of Hellmuth additionally Parasympathetic nervous systemwere described by Hans Asperger[1].

Interestingly, there is a complex, bidirectional interdependence between sex steroid hormones and epilepsy; hormones affect seizures, while seizures affect hormones thereby disturbing reproductive endocrine function[29]. Both female and male sex steroid hormones influence brain excitability, whereby for the female sex steroid hormones, progesterone and its metabolites are anticonvulsant, while estrogens are mainly proconvulsant[29]. Androgens are mainly anticonvulsant, but the effects are more varied, probably because of its metabolism to other steroid hormones such as estradiol[29]. The different sex steroids can also be further metabolized within the brain to different steroids, which are even more potent regarding their effect on excitability and for the development of an autistic phenotype[29]. Furthermore, E.g. estrogens altering brain morphology by increasing dendritic spine density and several studies have shown that epileptic activity, especially mediated through the amygdala, alters reproductive function, including reduced ovarian cyclicity in females and altered sex steroid hormone levels in both genders[29].

Furthermore, convulsions are ongoing with an asymmetric activation of the hypothalamus, which may, again, be the basis for the occurrence of different reproductive endocrine disorders described for patients with left-sided or right-sided temporal lobe epilepsy[29]. Furthermore, the suggested case of Cushing syndrome an involvement via Parathyroid might be possible. It was mentioned that Hellmuth was treated with Hypothalamus hormones but also thyroid hormones. May be, he was despite thyroid dysregulation also suffering from a dysfunction of Parathyroid with involvement of $\mathrm{Ca} 2+$ respectively Vitamin-D Metabolism which would be in line with a rachitis. This would be in accordance with the mentioned weak bones - as clinicians had the feeling that bones just do not exist and in line with an endocrine dysregulation on all layers of adrenal gland cortex (mineralocorticoid, glucocorticoid, androgens). Furthermore, the strong dysregulation of the parasympathetic nervous system innerved salvia gland allows to suggest of an involvement of Hypothalamus-pituitary adrenal gland axis. To sum up, clinicians should be aware of the endocrine symptoms when diagnosing autistic disorders and keep in mind other typical Pediatric diagnosis such as Turner $(45, \mathrm{X} 0)$ or Kinefeltersyndrom $(47, \mathrm{XXY})$ also ingoing with a dysregulation of sex hormones such as testosterone or estrogen and progesterone. Interestingly, the mother of Hellmuth was 41-year-old on birth date having a clear risk factor for chromosomal anomalies[30]. Concerning the effects of steroid hormones behavioural traits are key to understand autistic disorders.

These are possible to recognize before the second year of life and usually persist during the whole life-span [1,31-33]. Hints when working with these children were early made [34] and nowadays different recommendations concerning pedagogic acting can be found [17-20]. From a medical point of view, based on the suggestions longitudinal observations of all steroid lines during several years are recommended to conduct for autistic children allowing to elucidate mechanism of involvement during critical periods of development with the potential to yield to therapeutic recommendations [35-43].

\section{References}

1. Asperger H (1944) Die Autistischen Psychopathen im Kindesalter Archiv für Psychiatrie und Nervenkrankheiten 117: 76-136.

2. Delorme R, Ey E, Toro R, Leboyer M, Gillberg C, et al. (2013) Progress toward treatments for synaptic defects in autism. Nat Med 19(6): 685694.

3. Sarachana T, Xu M, Wu RC, Hu VW (2011) Sex hormones in autism: androgens and estrogens differentially and reciprocally regulate RORA, a novel candidate gene for autism. PLoS One 6(2): e17116.

4. Spratt EG, Nicholas JS, Brady KT, Carpenter LA, Hatcher CR, et al. (2012) Enhanced cortisol response to stress in children in autism. J Autism Dev Disord 42(1): 75-81.

5. Tani P, Lindberg N, Matto V, Appelberg B, Nieminen-von Wendt T, et al. (2005) Higher plasma ACTH levels in adults with Asperger syndrome. Psychosom Res 58(6): 533-536.

6. Hollocks MJ, Howlin P, Papadopoulos AS, Khondoker M, Simonoff E (2014) Differences in HPA-axis and heart rate responsiveness to psychosocial stress in children with autism spectrum disorders with and without co-morbid anxiety. Psychoneuroendocrinology 46: 32-45.

7. Jacobson L (2014) Hypothalamic-pituitary-adrenocortical axis: neuropsychiatric aspects. Compr Physiol 4(2): 715-738.

8. Taylor JL, Corbett BA (2014) A review of rhythm and responsiveness of cortisol in individuals with autism spectrum disorders. Psychoneuroendocrinology 49: 207-28.

9. Baron Cohen S, Auyeung B, Norgaard Pedersen B, Hougaard DM, Abdallah MW, et al. (2015) Elevated fetal steroidogenic activity in autism. Molecular Psychiatry 20(3): 369-376.

10. Majewska MR, Hill M, Urbanowicz E, Rok-Bujko R, Bien'kowski P, et al. (2014) Marked elevation of adrenal steroids, especially androgens, in saliva of prepubertal autistic children. Eur Child Adolesc Psychiatry 23: $485-498$

11. Bagnoli F, Mori A, Fommei C, Coriolani G, Badii S, et al. (2013) ACTH and cortisol cord plasma concentrations in preterm and term infants. J Perinatol 33(7): 520-524. 
12. Patrick RP, Ames BN (2014). Vitamin D hormone regulates serotonin synthesis. Part 1: relevance for autism. FASEB J 28(6): 2398-2413.

13. Kaneko I, Sabir MS, Dussik CM, Whitfield GK, Karrys A, et al. (2015) 1,25-Dihydroxyvitamin $\mathrm{D}$ regulates expression of the tryptophan hydroxylase 2 and leptin genes: implication for behavioral influences of vitamin D. FASEB J 29(9): 4023-4035.

14. Dean SL, McCarthy MM (2008) Steroids, sex and the cerebellar cortex: implications for human disease. Cerebellum 7(1): 38-47

15. Kuhl H (1996) Comparative pharmacology of newer progestogens. Drugs 51(2): 188-215.

16. Andrew S Brem, Robert B Bina, Thomas King, David J Morris (1997) $11 \beta 0 H$-Progesterone Affects Vascular Glucocorticoid Metabolism and Contractile Response. Hypertension 30: 449-454

17. Remschmidt, H \& Kamp-Becker, I (2006) Asperger-Syndrom. Springer Heidelberg, Germany.

18. Rollet, B \& Kastner-Koller U (1994) Praxisbuch Autismus. (3. Auflage) Urban \& Fischer, München, Germany.

19. Rollet B (2007) Einzelne therapeutische Massnahmen im Vergleich. In: Rollet, B. \& Kastner-Koller, U. (Hrsg.). Praxisbuch Autismus. Elsevier, München, Germany.

20. Rollet B A (2007) Autistische Kinder und Jugendliche mit guten bis sehr guten sprachlichen Fähigkeiten: Der Asperger-Autismus. In: Rollet, B \& Kastner-Koller, U. Praxisbuch Autismus. Für Eltern, Erzieher, Lehrer und Therapeuten (Eds), Urban \& Fischer, München, Germany.

21. Ingudomnukul E, Baron-Cohen S, Wheelwright S, Knickmeyer R (2007) Elevated rates of testosterone-related disorders in women with autism spectrum conditions. Horm Behav 51(5): 597-604.

22. Sarachana T, Hu VW (2013) Differential recruitment of coregulators to the RORA promoter adds another layer of complexity to gene (dys) regulation by sex hormones in autism. Mol Autism 4(1): 39.

23. Whitaker-Azmitia PM, Lobel M, Moyer A (2014) Low maternal progesterone may contribute to both obstetrical complications and autism. Med Hypotheses 82(3): 313-318.

24. Brown SL, Brown RM (2006) Selective Investment Theory: Recasting the Functional Significance of Close Relationships. Psychological Inquiry 17(1): 1-29.

25. Brown SL, Fredrickson BL, Wirth MM, Poulin MJ, Meier EA, et al. (2009) Social Closeness Increases Salivary Progesterone in Humans. Horm Behav 56(1): 108-111.

26. Tetsuka M, Takagi R, Ambo N, Myat TS, Zempo Y, et al.(2016) Glucocorticoid metabolism in the bovine cumulus-oocyte complex matured in vitro. Reproduction 151(1): 73-82.

27. Ingle DJ, Beary DF, Purmalis A(1953) Comparison of effect of progesterone and 11-ketoprogesterone upon glycosuria of partially depancreatized rat. Proc Soc Exp Biol Med 82(3): 416-419.

28. Schwarz E, Guest PC, Rahmoune H, Wang L, Levin Y, et al.(2011) Sexspecific serum biomarker patterns in adults with Asperger's syndrome. Mol Psychiatry 16(12): 1213-1220.
29. Taubøll E, Sveberg L, Svalheim S. Interactions between hormones and epilepsy. Seizure 28: 3-11.

30. Murakami K, Turale S, Skirton H, Doris F, Tsujino K, et al. (2016). Experiences regarding maternal age-specific risks and prenatal testing of women of advanced maternal age in Japan. Nurs Health Sci 18(1): 8-14.

31. Asperger H (1950) Die medizinischen Grundlagen der Heilpädagogik In: Mitschrift für Kinderheilkunde. Band 99, Wien S, pp. 105-107

32. Asperger H (1956) Heilpädagogik. Einführung in die Psychopathologie des Kindes für Aerzte, Lehrer, Psychologen, Richter und Fürsorgerinnen. Wien: Springer, Germany.

33. Asperger H (1975) Heilpädagogik. Wien Klin Wochenschr 87(18): 581-582.

34. Hamburger (1939) Die Neurosen des Kindesalters. Urban \& Schwarzenberg, Wien, Austria.

35. Brosnan M, Turner Cobb J, Munro-Naan Z, Jessop D. Absence of a normal cortisol awakening response (CAR) in adolescent males with Asperger syndrome (AS). Psychoneuroendocrinology 34(7): 10951100.

36. Cekic M, Johnson SJ, Bhatt VH, Stein DG (2012) Progesterone treatment alters neurotrophin/ proneurotrophin balance and receptor expression in rats with traumatic brain injury. Restor Neurol Neurosci 30(2): 115-126.

37. Crider A, Thakkar R, Ahmed AO, Pillai A (2014) Dysregulation of estrogen receptor beta (ER $\beta$ ), aromatase (CYP19A1), and ER coactivators in the middle frontal gyrus of autism spectrum disorder subjects. Mol Autism 5 (1): 46.

38. Gallagher JP, Orozco-Cabal LF, Liu J, Shinnick-Gallagher P (2008) Synaptic physiology of central CRH system. European Journal of Pharmacology 583(2-3): 215-225.

39. Hamza RT, Hewedi DH, Ismail MA (2010) Basal and adrenocorticotropic hormone stimulated plasma cortisol levels among Egyptian autistic children: relation to disease severity. Ital J Pediatr 36: 71.

40. Hoshino Y, Yokoyama F, Watanabe M, Murata S, Kaneko M, Kumashiro $H$ (1987) The diurnal variation and response to dexamethasone suppression test of saliva cortisol level in autistic children. Jpn J Psychiatry Neurol 41(2): 227-235.

41. Hoshino Y, Ohno Y, Murata S, Yokoyama F, Kaneko M, Kumashiro H (1984) Dexamethasone suppression test in autistic children. Folia Psychiatr Neurol Jpn 38(4): 445-449.

42. Marinović-Curin J, Marinović-Terzić I, Bujas-Petković Z, Zekan L, Skrabić $\mathrm{V}$, et al. (2008) Slower cortisol response during ACTH stimulation test in autistic children. Eur Child Adolesc Psychiatry 17(1): 39-43.

43. Mamidala MP, Polinedi A, Kumar PT, Rajesh N, Vallamkonda OR, et al. (2013) Maternal hormonal interventions as a risk factor for Autism Spectrum Disorder: an epidemiological assessment from India. J Biosci 38(5): 887-892. 
CC This work is licensed under Creative Commons Attribution 4.0 License

BY DOI: 10.19080/GJIDD.2018.04.555643
Your next submission with Juniper Publishers will reach you the below assets

- Quality Editorial service

- Swift Peer Review

- Reprints availability

- E-prints Service

- Manuscript Podcast for convenient understanding

- Global attainment for your research

- Manuscript accessibility in different formats ( Pdf, E-pub, Full Text, Audio)

- Unceasing customer service

Track the below URL for one-step submission https://juniperpublishers.com/online-submission.php 